\title{
TURISMO SEXUAL E A VIOLAÇÃO DE DIREITOS DAS MULHERES NEGRAS: QUANDO A MELANINA AGRAVA O PROBLEMA SOCIAL
}

\section{LORRAYNE CAROLINE ALVES PEREIRA}

Graduanda do curso de Direito, modalidade Integral - Escola Superior Dom Helder Câmara, Belo Horizonte - MG. E-mail: Lccalves.direito@gmail.com

\section{CAIO AUGUSTO SOUZA LARA}

Mestre e Doutor em Direito pela Faculdade de Direito da Universidade Federal de Minas Gerais - UFMG. Professor da Escola Superior Dom Helder Câmara. Pesquisador associado ao Programa RECAJ-UFMG - Acesso à Justiça e Solução de Conflitos. Secretário de Comunicação do Conselho Nacional de Pesquisa e Pósgraduação em Direito - CONPEDI. Belo Horizonte-MG. E-mail: caiolarabh@yahoo.com.br.

\section{RESUMO}

O tema-problema da pesquisa que se pretende desenvolver é a violação dos direitos das mulheres negras com o turismo sexual. Assim, partindo de uma análise histórica, durante o período escravocrata, os abusos sexuais, físicos e sociais eram comuns, a população negra não era considerada nada além de mero bem de seus proprietários. Posteriormente à abolição, em 1888, os recém libertos foram deixados a margem da sociedade, tendo eles que conseguir trabalhos de base, com péssimas remunerações e tratamento social segregacionista, por conseguinte, para as mulheres negras restavam apenas as funções de empregada doméstica e cuidadora de crianças, tendo algumas buscado como o refúgio para a sobrevivência a prostituição. Com isso, o prejuízo em sociedade fora gritante, o vexatório pelo descaso social, a fragilidade econômica juntamente ao estereótipo de mulher objeto que esteve 


\section{Personalidade Acadêmica Homenageada:}

Raymundo Juliano Feitosa (Universidade Federal do Rio Grande do Norte - UFRN)

presente na sociedade agravou-se assim como permanece até a contemporaneidade. Sendo assim, coisificação histórica da figura feminina em sua maioria negra reflete na atualidade com o desamparo social, agravado pela exploração e resultando no turismo sexual que auxilia diretamente no tráfico de pessoas no Brasil (UCHOA; NOGUEIRA; OLIVEIRA; OLIVEIRA, 2016). Por isso, traficantes de estrangeiros e brasileiros procuram lugares como o Brasil, por esse apresentar uma sociedade com vulnerabilidade social grande, já que, a pobreza das regiões exploradas corroboram para uma população mais ignorante e com situações que são mais suscetíveis a prostituição, e a coação para tentar uma vida com mais dignidade fora do país. As promessas de estabilidade financeira, melhores condições de vida, e até mesmo um relacionamento, leva mulheres a deixar toda sua história no Brasil e arriscarem a vida em países completamente desconhecidos, sendo eles na Eurásia principalmente (NÚMEROS de casos de tráfico de pessoas atinge recorde em 13 anos, indica relatório, 2019). Portanto, pergunta-se: como e com qual intensidade as mulheres negras têm seus direitos violados com o turismo sexual? Partindo da observação antelóquio do tema apresentado, o turismo sexual é um problema real no cenário internacional. Muitas mulheres, em sua maioria as de baixa renda e negras, são coagidas a se vincularem na indústria sexual devido as promessas o ganho de dinheiro rápido. Entretanto, o turismo sexual muitas vezes desencadeia para um tráfico humano, em que as mulheres vão para fora do país, são mantidas em cárcere privado e são obrigadas a trabalhar para pagar uma dívida interminável que as mantém em um trabalho escravo (CORDEIRO; SOBRAL; XEREZ, 2017). Sendo assim, o objetivo geral do trabalho é analisar como as mulheres negra têm seus direitos afetados com a exploração sexual desencadeando em um tráfico humano. A pesquisa que se propõe pertence à vertente metodológica jurídico-sociológica. No tocante ao tipo de investigação, foi escolhido, na classificação de Witker (1985) e Gustin (2010), o tipo jurídico-projetivo. O raciocínio desenvolvido na pesquisa será predominantemente dialético. De acordo com a técnica de análise de conteúdo, afirma-se que trata-se de uma pesquisa teórica o que será possível a partir da análise de conteúdo dos textos doutrinários, normas e demais dados colhidos na pesquisa. Após do exposto concluir-se que as mulheres apresenta-se em estado de desamparo 
Personalidade Acadêmica Homenageada:

Raymundo Juliano Feitosa (Universidade Federal do Rio Grande do Norte - UFRN)

perante a sociedade por conta de uma falta de uma educação de qualidade que não as auxilia. Também não recebem suporte para a obtenção de uma plena qualidade de vida. As desestruturas são tão graves e apresentam raízes a ponto das mulheres exporem-se a situações de risco como a prostituição, que pode acarretar em abusos e no tráfico humano, assim tirando o axioma mais essencial para a existência humana, sua dignidade.

PALAVRAS-CHAVE: Dignidade; Mulher; Negritude; Exploração; Turismo Sexual.

\section{REFERENCIAS}

AZEREDO, Caroline Machado de Oliveira. Dez Anos de Lei Maria da Penha: A Importância da Perspectiva de Gênero no Enfrentamento da Violência. Revista Jurídica - Unicuritiba, Curitiba, v.1 n.30, p. 91-111. Disponível: http://revista.unicuritiba.edu.br/index.php/RevJur/article/view/2126/1337. Acesso: 21 maio 2019.

CINDERELAS, lobos e um príncipe encantado 1 vídeo (1:47:58 minutos). Publicado pelo canal Gerleei Andrade. 18 de set de 2015. Disponível em: https://www.youtube.com/watch?v=6BZG-6heFXw. Acesso em: 11 de maio 2019.

CORDEIRO, Marília; SOBRAL, Viviane; XEREZ, Gioras. Mulheres do CE, BA, MG e SP eram traficadas para Europa via Fortaleza. Globo, Ceara, 15 fev. de 2017. Disponível em: http://g1.globo.com/ceara/noticia/2017/02/mulheres-do-ce-ba-mg-esp-eram-traficadas-para-europa-fortaleza.html. Acesso em: 21 maio de 2019

GUSTIN, Miracy Barbosa de Sousa; DIAS, Maria Tereza Fonseca. (Re)pensando a pesquisa jurídica: teoria e prática. $3^{a}$. ed. Belo Horizonte: Del Rey, 2010.

LOPES, A. C.B.; MALERBA, R. C. A. A imagem do Brasil como destino de turismo sexual na produção acadêmica de dissertações e teses (2001 - 2012). Caderno Virtual de Turismo. Rio de Janeiro, v. 15, n. 2, p.167-181, ago. 2015.

LINDE, Pablo. O mundo do turismo sexual infantil. El País, Madri, 9 ago. de 2014. Disponível em:https://brasil.elpais.com/brasil/2014/08/07/sociedad/1407435469_195076.html. Acesso em: 12 maio 2019.

MARIZ, Renata. Após declaração de Bolsonaro sobre o tema, estados lançam campanhas contra turismo sexual. Portal BBC Brasil, Rio de Janeiro, 05 maio. 2019. 
Personalidade Acadêmica Homenageada:

Raymundo Juliano Feitosa (Universidade Federal do Rio Grande do Norte - UFRN)

Disponível em: https://oglobo.globo.com/brasil/apos-declaracao-de-bolsonaro-sobretema-estados-lancam-campanhas-contra-turismo-sexual-23642854. Acesso em: 11 maio. 2019

MOTTA, Bruna. As religiões afro-brasileiras, o racismo e as opressões de gênero e a sexualidade. Esquerda Diário, Marília, 25 jul. 2015. Disponível em: https://www.esquerdadiario.com.br/As-religioes-afro-brasileiras-o-racismo-e-asopressoes-de-genero-e-sexualidade. Acesso em: 08 maio 2019.

NÚMERO de casos de pessoas atinge recorde em 13 anos, indica relatório. ONUBR, Rio de Janeiro, 01 jan. de 2019. Disponível em: https://nacoesunidas.org/numero-decasos-de-trafico-de-pessoas-atinge-recorde-em-13-anos-indica-relatorio/amp/.

Acesso em: 21 maio 2019.

TURISMO e prostituição na copa do mundo: Enquadramentos midiáticos sobre turismo sexual. Revista Passagens. Ceara. Volume 6. Número 1. 2015. Páginas 138155.

WITKER, Jorge. Como elaborar una tesis en derecho: pautas metodológicas y técnicas para el estudiante o investigador del derecho. Madrid: Civitas, 1985. 